\title{
Commentary: Teratogenic effects of the Zika virus and the role of the placenta
}

\author{
Shu Yuan ${ }^{1 * t}$, Qin Luo ${ }^{2+}$, Zhong-Wei Zhang ${ }^{1}$ and Zi-Lin $\mathrm{Li}^{3}$ \\ ${ }^{1}$ College of Resources, Sichuan Agricultural University, Chengdu, China, ${ }^{2}$ School of Biomedical Sciences, Chengdu Medical \\ College, Chengdu, China, ${ }^{3}$ General Hospital of Lanzhou Military Region, Lanzhou, China
}

Keywords: Zika virus, microcephaly, placental barrier, virus transfer, treatment time window, infection time

\section{A commentary on}

Teratogenic effects of the Zika virus and the role of the placenta

by Adibi, J. J., Marques, E. T. Jr., Cartus, A., and Beigi, R. H. (2016). Lancet 387, 1587-1590. doi: 10. 1016/S0140-6736(16)00650-4

\section{OPEN ACCESS}

Edited by:

Juan-Carlos Saiz

Instituto Nacional de Investigación y

Tecnología Agraria y Alimentaria (INIA),

Spain

Reviewed by:

Sunnie R. Thompson,

University of Alabama at Birmingham,

USA

Rosalia Mendez-Otero,

Federal University of Rio de Janeiro,

Brazil

*Correspondence:

Shu Yuan

roundtree318@hotmail.com

${ }^{\dagger}$ These authors have contributed equally to this work

Received: 01 December 2016 Accepted: 20 February 2017 Published: 03 March 2017

Citation:

Yuan S, Luo Q, Zhang Z-W and Li Z-L (2017) Commentary: Teratogenic effects of the Zika virus and the role of

the placenta.

Front. Cell. Infect. Microbiol. 7:62. doi: 10.3389/fcimb.2017.00062
A widespread epidemic of Zika virus (ZIKV) infection was reported recently in South and Central America. The biggest concern to the ZIKV infection is the significant increase of microcephaly in the fetus born to the infected mother (Brasil et al., 2016; Johansson et al., 2016; Mlakar et al., 2016). The placenta acts as a barrier against the infection, due to its multiple unique structural, cellular and immune properties. However, the placenta may also play an important role in the virus transfer. One possibility is that the virus penetrates through the placental barrier. Zika virus could be packaged as a cargo for the placental exosome pathway at the endoplasmic reticulum in trophoblast cells. Then the secretory autophagy-pathway may cause secretion or expulsion of the viral particle rather than its degradation (Zhang et al., 2017). Alternatively, the infection to the placenta may induce several immune responses and lead to brain defects indirectly (Adibi et al., 2016). A recent study indicated that the ZIKV genome could be detected in the amniotic fluid (Calvet et al., 2016), and the complete genome of ZIKV can be also recovered from the fetal brain (Mlakar et al., 2016), all of which confirm that the virus can cross the placental barrier (Mysorekar and Diamond, 2016).

In vitro studies confirmed that ZIKV, but not the closely related dengue virus or West Nile virus, can infect key placental barrier cells efficiently (Richard et al., 2017). Although some reports indicated that Zika virus infection triggers apoptosis and vascular damage in the placenta, which may increase the permeability of the placenta (Aldo et al., 2016; Melo et al., 2016; Miner et al., 2016), two recent studies suggested that most trophoblast cells succeed in blocking ZIKV infection or only permitting a very low viral replication level (Bayer et al., 2016; Quicke et al., 2016). However, no other pathogenic flaviviruses cause congenital defects. Miner and colleagues' work mainly focused on placental and fetal cytological changes. They found that ZIKV infection induces trophoblast apoptosis and vascular damages in the placenta (Miner et al., 2016). El Costa et al. (2016) also demonstrated that ZIKV infects and damages tissue architecture of the fetal placenta, the maternal decidua basalis and umbilical cord. The structure of the placenta is complex, which is comprised of the maternal decidua and the fetal-derived compartments, including the labyrinth and junctional zones. Different types of trophoblast cells reside within all three layers. In the labyrinth-zone, fetal capillaries are lined by fetal blood vessel endothelium, which are segregated from maternal sinusoids by a layer of mono-nuclear trophoblasts and a syncytio-trophoblast bilayer (Adibi et al., 2016; Miner et al., 2016). However, only minimal trophoblast cell death was observed after the infection (Quicke et al., 2016) and thus the placental barrier might remain relatively intact. 
TABLE 1 | Time intervals between infections and abnormal findings of fetuses.

\begin{tabular}{|c|c|c|c|}
\hline Fetus/Case No. (Reference) & $\begin{array}{l}\text { Week of gestation at } \\
\text { Infection }\end{array}$ & $\begin{array}{l}\text { Week of gestation at the time of first abnormal finding of } \\
\text { the fetus or the time of birth }\end{array}$ & $\begin{array}{l}\text { Predicted time length of } \\
\text { viral placental transfer } \\
\text { (Weeks) }\end{array}$ \\
\hline Case 1 (Noronha et al., 2016) & 7 & $\begin{array}{l}\text { Miscarried at } 12 \text { weeks } \\
\text { (No fetal virus or neurological abnormality was found) }\end{array}$ & $>5$ \\
\hline Case 5 (Noronha et al., 2016) & 32 & $\begin{array}{l}\text { Birth at } 37 \text { weeks } \\
\text { (No fetal virus or neurological abnormality was found) }\end{array}$ & $>5$ \\
\hline Case 1 (Soares de Souza et al., 2016) & 36 & $\begin{array}{l}\text { Birth at } 38 \text { weeks } \\
\text { (subependymal cysts and lenticulostriate vasculopathy at birth, } \\
\text { however has a normal neurological development later) }\end{array}$ & $>2$ \\
\hline Case 2 (Soares de Souza et al., 2016) & 36 & $\begin{array}{l}\text { Birth at } 39 \text { weeks } \\
\text { (subependymal cysts at birth, however has a normal neurological } \\
\text { development later) }\end{array}$ & $>3$ \\
\hline Fetus 24 (Brasil et al., 2016) & 12 & 29 & 17 \\
\hline Fetus 41 (Brasil et al., 2016) & 12 & 24 & 12 \\
\hline Fetus 39 (Brasil et al., 2016) & 21 & 30 & 9 \\
\hline Fetus 17 (Brasil et al., 2016) & 22 & 26 & $>4$ \\
\hline Fetus 12 (Brasil et al., 2016) & 22 & 27 & 5 \\
\hline Fetus 10 (Brasil et al., 2016) & 25 & 30 & 5 \\
\hline Fetus 36 (Brasil et al., 2016) & 26 & 35 & 9 \\
\hline Fetus 38 (Brasil et al., 2016) & 27 & 35 & 8 \\
\hline Fetus 2 (Brasil et al., 2016) & 30 & $\begin{array}{l}\text { Birth at } 34 \text { weeks } \\
\text { (Normal at birth) }\end{array}$ & $>4$ \\
\hline Fetus 53 (Brasil et al., 2016) & 32 & $\begin{array}{l}\text { Still birth } \\
\text { (Fetal death at } 38 \text { weeks) }\end{array}$ & 6 \\
\hline Fetus 23 (Brasil et al., 2016) & 35 & $\begin{array}{l}\text { Birth at } 40 \text { weeks } \\
\text { (Electroencephalogram abnormalities) }\end{array}$ & 5 \\
\hline
\end{tabular}

On the other hand, the placenta continues to produce trophoblast-derived interferons and other trophoblast-specific antiviral factors (Bayer et al., 2016; Quicke et al., 2016). Therefore, most ZIKV was blocked by trophoblast cells and the viral placental transfer might be a time-consuming process.

Placental transfer suggests that ZIKV must be transferred to the embryo at the early brain development stage (e.g., at the first trimester; Mlakar et al., 2016). However, at that time, the embryo has been shielded from the maternal blood, which nevertheless flows into the placenta only after 10 weeks of gestation (Adibi et al., 2016). Consistent with these structure changes, a tissuelevel analysis in a case where the mother was infected at 7 weeks and miscarried at 12 weeks confirmed that the trophoblast was not infected by ZIKV at that period (Noronha et al., 2016). Thus, the virus may not reach the embryo before the first trimester.

However, for cases of ZIKV exposure in pregnancy, it is established that the greatest risk of microcephaly is in the preconception period and the first trimester (Johansson et al., 2016). In a case of late pregnancy, where infection occurred at 32 weeks, the virus was not detected in the fetal circulation, but it was detected in the placenta (Noronha et al., 2016). Similarly, in two cases of infection at 36 weeks, the virus was not detected in the infant's blood, although the newborns showed subependymal cysts (a kind of cerebral cysts) and lenticulostriate vasculopathy (lenticulostriate artery deformation) and they had normal neurological development for age as of the first postnatal month (Soares de Souza et al., 2016). Therefore, the viral placental transfer may take some time. Analysis of the clinical data (Brasil et al., 2016; Noronha et al., 2016; Soares de Souza et al., 2016) suggests that the virus may take about 5 weeks to reach the fetus for most cases (Table $\mathbf{1}$ ).

As mentioned above, ZIKV infections may also induce acute inflammatory responses with up-regulation of interferons and cytokines and the indirect effects to the fetus (Adibi et al., 2016; Bayer et al., 2016; Mor, 2016; Quicke et al., 2016). Two case reports from Soares de Souza et al. (2016) indicated some congenital brain injuries in the blood ZIKVnegative fetuses (or the virus levels were under the limit of detection). The fetal brain injuries may be caused by the maternal infection indirectly, if the virus did not reach the fetus birth. Besides ZIKV, other flaviviruses also induce the cytokine storm. However, no relevance between any other flavivirus and microcephaly has been reported so far. Thus inflammatory responses may not play a major role in the incidence of lethal microcephaly.

We can postulate that if most ZIKV was cleared before it reaches the fetus, the incidence of microcephaly may be greatly decreased. The interferon therapy might help to clear the virus within 5 weeks. Alternatively, a combination of interferon with vaccines, newly-developed antiviral agents (e.g. $2^{\prime}$-C-methylated nucleosides; Eyer et al., 2016) or exosomespecific inhibitors (Zhang et al., 2017) should be adopted for this therapeutic time window. The infection early in pregnancy may give the virus plenty of time to transfer through the 
placental barrier. And if the infection occurs early in pregnancy, the treatment window would be even longer, perhaps over 12 weeks.

\section{AUTHOR CONTRIBUTIONS}

SY coordinated the writing and wrote this manuscript together with inputs form all other listed co-authors. SY and QL made equal contributions in finalizing this manuscript.

\section{REFERENCES}

Adibi, J. J., Marques, E. T. Jr., Cartus, A., and Beigi, R. H. (2016). Teratogenic effects of the Zika virus and the role of the placenta. Lancet 387, 1587-1590. doi: 10.1016/S0140-6736(16)00650-4

Aldo, P., You, Y., Szigeti, K., Horvath, T. L., Lindenbach, B., and Mor, G. (2016). HSV-2 enhances ZIKV infection of the placenta and induces apoptosis in first-trimester trophoblast cells. Am. J. Reprod. Immunol. 76, 348-357. doi: 10.1111/aji.12578

Bayer, A., Lennemann, N. J., Ouyang, Y., Bramley, J. C., Morosky, S., Marques, E. T. Jr., et al. (2016). Type III interferons produced by human placental trophoblasts confer protection against Zika virus infection. Cell Host Microbe 19, 705-712. doi: 10.1016/j.chom.2016.03.008

Brasil, P., Pereira, J. P. Jr., Moreira, M. E., Ribeiro Nogueira, R. M., Damasceno, L., Wakimoto, M., et al. (2016). Zika virus infection in pregnant women in Rio de Janeiro. N. Engl. J. Med. 375, 2321-2334. doi: 10.1056/NEJMoa1602412

Calvet, G., Aguiar, R. S., Melo, A. S., Sampaio, S. A., de Filippis, I., Fabri, A., et al. (2016). Detection and sequencing of Zika virus from amniotic fluid of fetuses with microcephaly in Brazil: a case study. Lancet Infect. Dis. 16, 653-660. doi: 10.1016/S1473-3099(16)00095-5

El Costa, H., Gouilly, J., Mansuy, J. M., Chen, Q., Levy, C., Cartron, G., et al. (2016). ZIKA virus reveals broad tissue and cell tropism during the first trimester of pregnancy. Sci. Rep. 6, 35296. doi: 10.1038/srep35296

Eyer, L., Nencka, R., Huvarová, I., Palus, M., Joao Alves, M., Gould, E. A., et al. (2016). Nucleoside Inhibitors of Zika Virus. J. Infect. Dis. 214, 707-711. doi: 10.1093/infdis/jiw226

Johansson, M. A., Mier-y-Teran-Romero, L., Reefhuis, J., Gilboa, S. M., and Hills, S. L. (2016). Zika and the risk of microcephaly. N. Engl. J. Med. 375, 1-4. doi: 10.1056/NEJMp1605367

Melo, A. S., Aguiar, R. S., Amorim, M. M., Arruda, M. B., Melo, F. O., Ribeiro, S. T., et al. (2016). Congenital Zika virus infection: beyond neonatal microcephaly. JAMA Neurol. 73, 1407-1416. doi: 10.1001/jamaneurol.2016.3720

Miner, J. J., Cao, B., Govero, J., Smith, A. M., Fernandez, E., Cabrera, O. H., et al. (2016). Zika virus infection during pregnancy in mice causes placental damage and fetal demise. Cell 165, 1081-1091. doi: 10.1016/j.cell.2016. 05.008

\section{FUNDING}

This work was funded by the Preeminent Youth Fund of Sichuan Province (2015JQO045).

\section{ACKNOWLEDGMENTS}

We thank LetPub (www.letpub.com) for its linguistic assistance during the preparation of this manuscript.

Mlakar, J., Korva, M., Tul, N., Popović, M., Poljšak-Prijatelj, M., Mraz, J., et al. (2016). Zika virus associated with microcephaly. N. Engl. J. Med. 374, 951-958. doi: 10.1056/NEJMoa1600651

Mor, G. (2016). Placental inflammatory response to Zika virus may affect fetal brain development. Am. J. Reprod. Immunol. 75, 421-422. doi: 10.1111/aji.12505

Mysorekar, I. U., and Diamond, M. S. (2016). Modeling Zika virus infection in pregnancy. N. Engl. J. Med. 375, 481-484. doi: 10.1056/NEJMcibr1605445

Noronha, L. D., Zanluca, C., Azevedo, M. L., Luz, K. G., and Santos, C. N. (2016). Zika virus damages the human placental barrier and presents marked fetal neurotropism. Mem. Inst. Oswaldo Cruz 111, 287-293. doi: 10.1590/0074-02760160085

Quicke, K. M., Bowen, J. R., Johnson, E. L., McDonald, C. E., Ma, H., O’Neal, J. T., et al. (2016). Zika virus infects human placental macrophages. Cell Host Microbe 20, 83-90. doi: 10.1016/j.chom.2016.05.015

Richard, A. S., Shim, B. S., Kwon, Y. C., Zhang, R., Otsuka, Y., Schmitt, K., et al. (2017). AXL-dependent infection of human fetal endothelial cells distinguishes Zika virus from other pathogenic flaviviruses. Proc. Natl. Acad. Sci. U.S.A. 114, 2024-2029. doi: 10.1073/pnas.1620558114

Soares de Souza, A., Moraes Dias, C., Braga, F. D., Terzian, A. C., Estofolete, C. F., Oliani, A. H., et al. (2016). Fetal infection by Zika virus in the third trimester: report of 2 cases. Clin. Infect. Dis. 63, 1622-1625. doi: 10.1093/cid/ciw613

Zhang, Z. W., Li, Z. L., and Yuan, S. (2017). The role of secretory autophagy in Zika virus transfer through the placental barrier. Front. Cell. Infect. Microbiol. 6:206. doi: $10.3389 /$ fcimb. 2016.00206

Conflict of Interest Statement: The authors declare that the research was conducted in the absence of any commercial or financial relationships that could be construed as a potential conflict of interest.

Copyright (C) 2017 Yuan, Luo, Zhang and Li. This is an open-access article distributed under the terms of the Creative Commons Attribution License (CC BY). The use, distribution or reproduction in other forums is permitted, provided the original author(s) or licensor are credited and that the original publication in this journal is cited, in accordance with accepted academic practice. No use, distribution or reproduction is permitted which does not comply with these terms. 